\title{
Asset Prices, Real Exchange Rate and Current Account Fluctuations: Some Structural VAR Evidence for Thailand
}

\author{
Komain Jiranyakul \\ School of Development Economics, National Institute of Development Administration \\ 118 Seri Thai Road, Bangkapi, Bangkok 10240, Thailand \\ E-mail: komain_j@hotmail.com
}

Received: June 19, 2017 Accepted: July 23, 2017

doi:10.5296/ber.v7i2.11674 URL: https://doi.org/10.5296/ber.v7i2.11674

\begin{abstract}
This paper is motivated by the controversial issue in the literature pertaining to the impact of real exchange rate, housing prices and stock prices on current account fluctuations. Thailand's quarterly data are used to examine the impacts of shocks to asset prices and real exchange rate on the current imbalances. The paper employs a structural VAR methodology with short-run restrictions. The estimates of structural VAR models are able to identify interactions among asset prices, real exchange rate, and the current account. The estimated results from two different structural models show that the responses of current account to shocks are different. It can be concluded that shocks to real exchange rate affect current account and that shocks to real housing prices can better explain current account fluctuations than shocks to real stock prices. Based upon the results from this study, policymakers should take into account the importance of shocks to real exchange rate and real housing prices that can affect the current account of the country.
\end{abstract}

Keywords: Housing prices, Stock prices, Real exchange rate, Current account, Structural vector auto-regression

\section{Introduction}

Theoretically, current account imbalance in an economy depends on various factors, especially real exchange rate, stock prices and housing prices (Fratzscher abd straub, 2009). In addition, some evidence indicates that many shocks can also cause current account fluctuations (e.g. Fratzscher et al., 2010). Shocks that cause trade imbalances can also cause current account imbalances because merchandized trade accounts for a large portion of the 


\section{Macrothink}

Business and Economic Research

ISSN 2162-4860

2017, Vol. 7, No. 2

current account in most open economies. There exists a structural model that is able to explain interactions among asset prices (housing and stock prices), real exchange rate and current account fluctuations (Blanchard et al., 2005). The model also helps researchers identifying how the current account responds to real exchange rate and asset prices. However, empirical evidence on the roles of stock and housing markets on the current account is inconclusive. Besides the impact of real exchange rate on current account, stock and housing markets are the other two important factors that can exert the impacts on the current account (e.g., Fratzscher and Straub, 2009).

The present study is motivated by the controversial issue in the literature in that it explores the relative importance of shocks to housing prices and stock prices on the current account in Thailand, which is one of emerging market economies in the Southeast Asian region. Some facts of the current account, trends in housing and stock prices are as the followings. The current account to nominal GDP ratio is calculated during the 2008Q1-2016Q2 period. Figure 1 plots current account balances for Thailand.

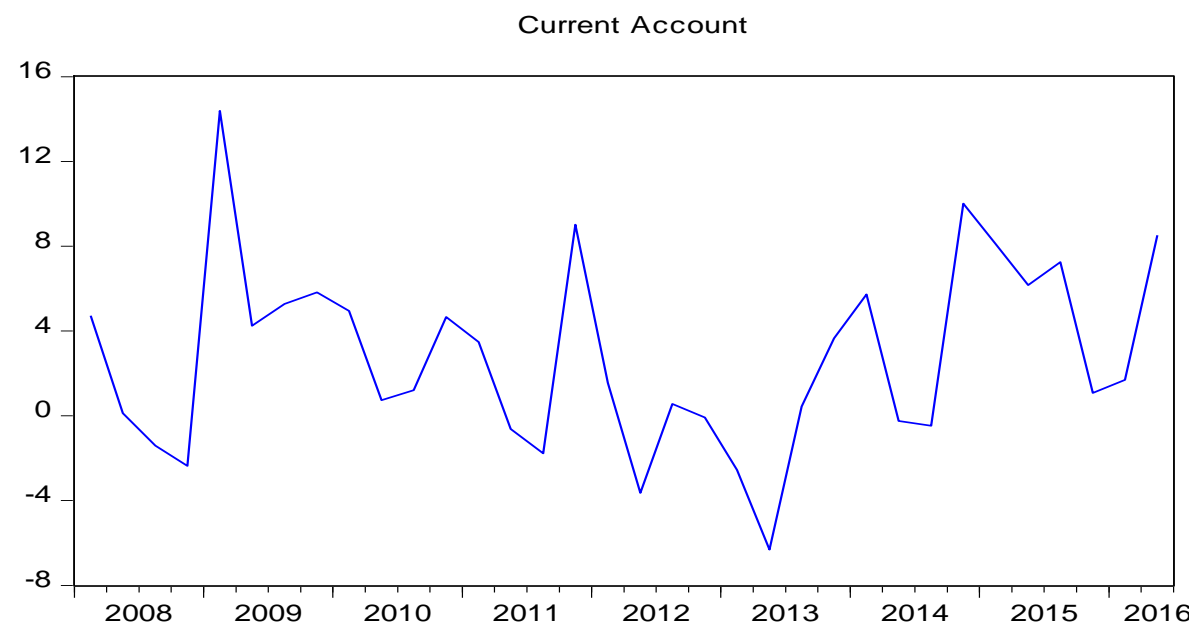

Figure 1. Current Account Imbalances during 2008Q1 and 2016Q2

The current account imbalances are measured by fluctuations in the ratio between nominal current account balance and nominal GDP (percent). The ratios which are above zero indicate current account surpluses while the ratios which are below zero indicate current account deficits. This current account ratio experienced an up-and-down moving pattern with most surpluses during the period. The highest surplus of 14.4 percent of GDP occurred in the first quarter of 2009 and fluctuated with a decreasing trend. This ratio reached the highest deficit of 6.3 percent of GDP in the second quarter of 2013. The improvement in current account balances was observed thereafter. 


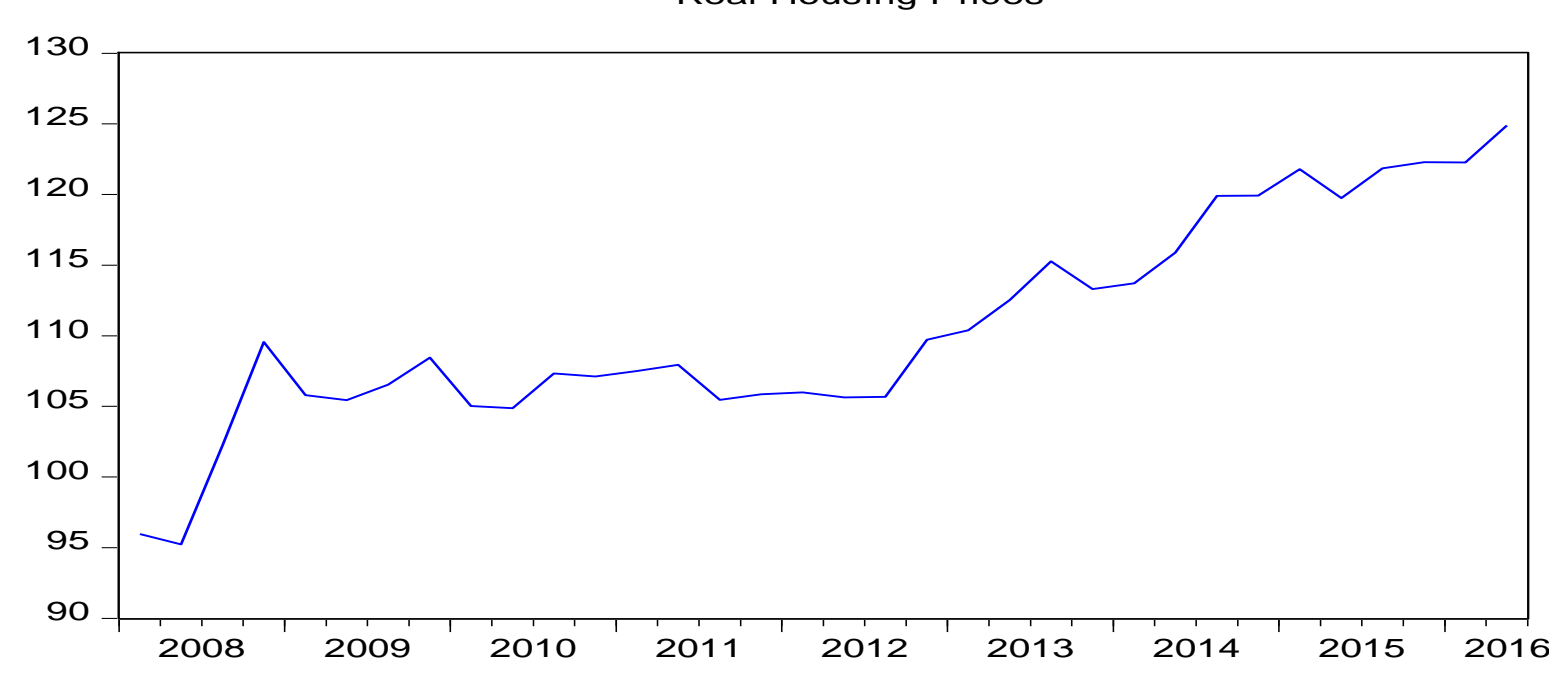

a. Real Housing Prices

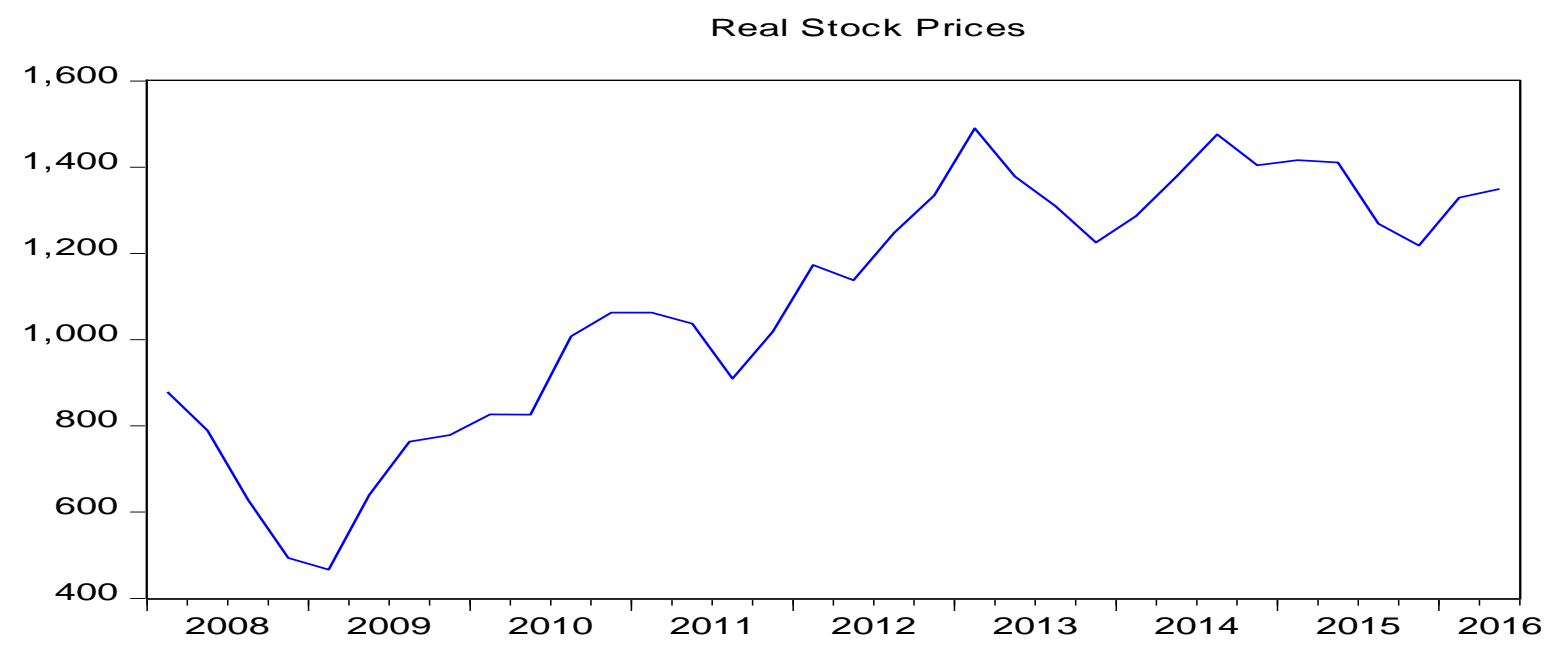

b. Real Stock Prices

Figure 2. Asset Prices Movements during 2008Q1 and 2016Q2

Figure 2 plots asset price movements during the period of study. Real housing prices are measured by housing price index deflated by consumer price index while real stock prices are measured by stock market index deflated by consumer price index. In Figure 2a, housing prices sharply increased at the end of 2008 and slightly declined with some fluctuations until 2012. Thereafter, a rising trend was observed. Stock prices in Figure $2 b$ had a similar trend, but sharply decreased at the beginning and increased with the up-and-down moving pattern thereafter. Figure 1 combined with Figure 2 show that the increasing trends of both housing and stock prices do not seem to be in line with the fluctuations in current account. 
Real Exchange Rate

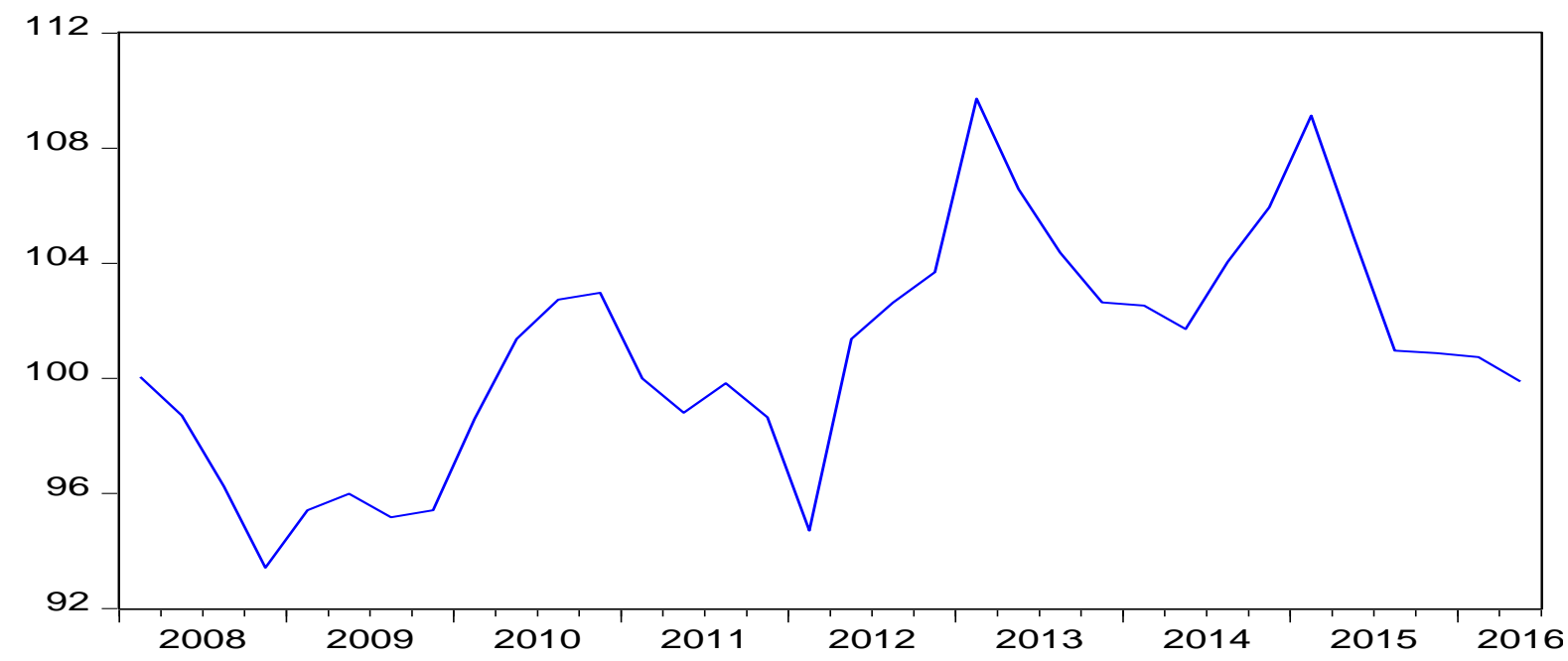

Figure 3. Behavior of Real Effective Exchange Rate during 2008Q1 and 2016Q2

Real exchange rate is an index of weighted average of major exchange rates. A rise in this index indicates real depreciation of domestic currency while a fall in this index indicates real appreciation of domestic currency. The behavior of real effective exchange rate can be seen in Figure 3. Real effective exchange rate fluctuated during the period of investigation. Figure 3 combined with Figure 1 show that most of current account deficit was accompanied by appreciation of real exchange rate. The highest deficit that occurred in the second quarter of 2013 was associated with a sharp drop in real exchange rate (real appreciation).

This paper addresses the following questions: (1) Can shocks to real exchange rate and asset prices explain current account imbalances? and (2) Are the impacts of shocks to housing prices are more pronounced than the impacts of shocks to stock prices on the current account? This paper contributes to the existing literature in that it provides evidence that the impacts of shocks to stock prices, housing prices and real exchange rate on the current account are observed in an emerging market economy during the period of investigation. The structural vector autoregressive (SVAR) model is used in the analysis to show that the impact of housing price shocks on the current account is more pronounced than the impact of stock price shocks. A shock to housing prices imposes a positive impact on current account balance while a shock to stock prices does the opposite. The rest of this paper is organized as follows: Section 2 gives a brief literature review. Section 3 describes the data and the methods that are used in the analysis. Section 4 describes the empirical results and some discussion and the last section concludes.

\section{Literature Review}

Controversial debates among researchers about what factors determine current account have been triggered since the emergence of current account imbalances in advanced countries in the past. In previous empirical studies, there are many shocks that cause current account fluctuations. Ahmed and Park (1994) find that domestic absorption shocks are the crucial shocks explaining trade balances in small open economics. Obstfeld and Rogolf (1995) indicate that real exchange rate movements cause current account fluctuations even in new 
open economies while Blanchard and Giavazzi (2002) point to the importance of the current account effects of exchange rate shifts. A decrease in real exchange rate can cause a large current account deficit and vice versa. Blanchard et al. (2005) indicate that main forces behind the large US current account deficits are an increase in US demand for foreign goods and an increase in foreign demand for US assets along with an appreciation of the US dollar. However, Krugman (2007) points out that the sharp drop in the US dollar can cause the crisis, but it is not clear if this crisis can cause macroeconomic problems. Chinn and Lee (2009) estimate the proportion of current account that will adjust through the exchange rate channel for the US, Japan and the Euro area. They find that the US needs to undergo real exchange rate depreciation to alleviate current account deficits while Japan and the Euro area need to undergo real exchange rate appreciation to reduce current account surpluses. Sek and Chuah (2011) examine the role of exchange rate in explaining the dynamic of current account movements in Indonesia, Malaysia, Philippines, Singapore, Thailand and South Korea before and after the 1997 Asian financial crisis. They find that the impacts of exchange rate shocks on current account imbalances have been declined after the financial crisis because these economies adjust the monetary stances under the floating exchange rate regime. Mirdara (2013) finds that exchange rates determine current accounts in European transition economies, and shocks to exchange rate after the crisis cause improvements in current accounts of these economies. Ballano and Ibrahimaj (2015) use a panel VAR model to examine the determinants of current accounts for a sample of eleven Central and East European countries outside the Euro area. They find that real effective exchange rate is one of key determinants of current accounts in these emerging market economies. Beckmann and Czudcy (2016) examine common exchange rate and current account dynamics across countries based on common factors. They find that a real appreciation coincides with current account deficits in most countries. For a global point of view, cross- country trends that drive exchange rates and current accounts share similar dynamics in the long run.

For the role of stock and housing markets on current account fluctuations, Mercereau (2003) develops a simple model to analyze the impact of stock markets on the current account. The model suggests that it is optimal for a country to run current account deficit even though people do not expect the stock boom to last. Furthermore, the current account may help predict future stock market performance in the sense of causal relationship. Lee and Chinn (2006) indicate that two of various shocks that can affect current account are real exchange rates and asset prices. They find that temporary shocks to these two variables have only short-run effects on current account. Fratzscher and Straub (2009) examine the impact of equity-price shocks on current account positions for the G-7 economies during 1974 and 2007. They find that such shocks impose a sizable impact. However, the impacts vary across countries. Holinski and Vermeulen (2012) examine whether shocks to asset prices transmit into the trade balance for a group of five most industrialized countries. They find that a negative stock price shock causes trade balance to improve for the US, UK and France. This impact is not observed for Germany and Japan. In addition, a negative shock to UK housing prices also improves the trade balance. Fratzscher et al. (2010) find that equity market shocks and housing price shocks are major determinants of the US current account. The real exchange rate shocks are less relevant and exert only temporary effect on the US trade 
balance. Berg (2013) uses a panel vector autoregressive (VAR) model to examine the relationship between stock prices and current account for 17 OECD countries during 1980 and 2007 and finds that shocks to stock prices and exchange rates have sizable effects on current account. Fratzcher and Straub (2013) investigate the relationship between asset prices and trade balance in 38 industrialized and emerging market economies. They find that domestic equity price shocks exert a sizable impact on trade balance, especially for the US. The impacts are less pronounced in other economies. Antonakakis et al. (2015) employ time-varying approach to examine dynamic correlations of trade balance and stock prices in the US during 1792 and 2013. They find that the correlations are positive during 1800 and 1870, and negative thereafter. Therefore, the relationship between stock prices and trade balance can be either positive or negative depending on the signs of the wealth effect channel and the exchange rate channel. Recent study that emphasizes the relationship between housing prices and current accounts by Arestis et al. (2016) show that there is a positive relationship between house prices and current account imbalances in a theoretical framework. This positive relationship stems from the fact that housing prices and current account imbalances are driven by common fundamentals. This theory is able to explain the fact that some OECD economies whose housing markets have collapsed exhibit current account imbalances. Using a Bayesian VAR approach to investigate the relationship between house prices and trade balance in South Africa, Simo-Kengne et al. (2015) find that a decline in housing prices improves the trade balance. A decrease in housing prices cause income and thus consumption to decrease. Households tend to consume less imports and thus the balance of trade to improve. Therefore, housing prices represent an additional factor besides the exchange rate channel.

\section{Data and Methodology}

This section explains the data and the applied econometric methods used in the analysis.

\subsection{Data}

The data are obtained from various sources. Nominal current account balance, real effective exchange rate and housing price indexes are obtained from the Bank of Thailand. The consumer price index is obtained from Ministry of Commerce while nominal GDP is obtained from the office of National Economic and Social Development Board. Stock prices are retrieved from the website of the Stock Exchange of Thailand.

The dataset used in this study comprises quarterly data from 2008Q1 to 2016Q2 with 34 observations. ${ }^{1}$ The variables used in the analysis are current account, real asset prices and real exchange rate. The current account variable is defined as the ratio of nominal current account balance and nominal GDP. The asset prices are housing price and stock market prices are measured by indexes. These two indexes are deflated by consumer price index to convert them to real price series. The real exchange rate variable is the series of real effective exchange rate index, which is the weighted average of major currencies. The tests for unit

\footnotetext{
${ }^{1}$ The sample size is limited by the availability of housing price index. The housing price index of single detached house is used.
} 
root are conducted to determine the order of integration of these variables. The results are reported in Table 1.

Table 1. Results of Unit Root Tests

\begin{tabular}{|l|l|l|}
\hline Variable & $\mathrm{PP}(\mathrm{c})$ & $\mathrm{PP}(\mathrm{c}+\mathrm{t})$ \\
\hline Level: & & \\
\hline$c a$ & $-4.392 * * *(0.002)$ & $-4.348 * * *(0.000)$ \\
\hline reer & $-0.256(0.263)$ & $-2.581(0.291)$ \\
\hline$h p$ & $-0.938(0.763)$ & $-2.435(0.356)$ \\
\hline$s p$ & $-0.861(0.788)$ & $-2.240(0.240)$ \\
\hline First Difference & & \\
\hline$\Delta r e e r$ & $-5.058 * * *(0.001)$ & $-4.959 * * *(0.001)$ \\
\hline$\Delta h p$ & $-5.633 * * *(0.000)$ & $-5.539 * * *(0.001)$ \\
\hline$\Delta s p$ & $-4.643 * * *(0.001)$ & $-5.454 * * *(0.001)$ \\
\hline
\end{tabular}

Note: The variables are: $c a$ (current account balance to GDP), reer (real effective exchange rate index, $h p$ (real housing price index) and $s p$ (real stock market index). *** denotes significance at the 1 percent level.

The Phillips and Perron (PP) tests with constant $(c)$ and with constant and a linear trend $(c+t)$ are performed. The results in Table 1 show that the variable $c a$ does not contain a unit root and thus it is $\mathrm{I}(0)$ series. Other variables contain a unit root and thus they are $\mathrm{I}(1)$ series.

The contemporaneous correlations between each pair of variables are shown in Table 2.

Table 2. Contemporaneous Correlation

\begin{tabular}{|l|l|l|l|l|}
\hline & $c a$ & reer & $h p$ & $s p$ \\
\hline ca & 1.000 & & & \\
\hline reer & -0.136 & 1.000 & & \\
\hline$h p$ & 0.199 & 0.450 & 1.000 & \\
\hline$s p$ & -0.116 & 0.806 & 0.683 & 1.000 \\
\hline
\end{tabular}

Note: The variables are: $c a$ (current account balance to GDP), reer (real effective exchange rate index, $h p$ (real housing price index) and $s p$ (real stock market index).

Table 2 shows that correlation coefficient between current account and real exchange rate is negative, which implies that real appreciation of the exchange rate leads to a deterioration in current account while real depreciation of the exchange rate leads to an improvement in current account. The positive correlation coefficient between real housing prices and current account is low while the negative correlation coefficient between real stock prices and current account is also low. The highest correlation coefficient of 0.806 is between real stock prices and real exchange rate. In addition, the positive correlation coefficient between real housing prices and real stock prices is quite high. Since this study attempts to identify the impacts of different shocks to current account, each structural model should be estimated separately as mentioned in the next sub-section. 


\subsection{Structural VAR Model}

The underlying structural equation is expressed as:

$$
A Y_{t}=C(L) Y_{t}+B u_{t}
$$

where $u_{t}$ is the stochastic error, which is normally distributed with mean of zero and constant variance. However, equation (1) cannot be estimated directly due to identification issues. Instead, the alternative unrestricted VAR model can be estimated and the model can be expressed as:

$$
Y_{t}=A^{-1} C(L) Y_{t}+A^{-1} B u_{t}
$$

Since matrices $A, B$ and $C$ in equation (1) are not separately observable, equation (1) can be recovered from equation (2) by imposing restrictions on the specified VAR model to identify an underlying structure. This is the model proposed by Blanchard and Quah (1989).

A simple model is defined for the estimation of the VAR model, which comprises three variables. The first VAR model is [ca, reer, hp] and the second model is [ca, reer, sp]. In the first step of estimation, an unrestricted VAR model with three variables in their levels with a constant is estimated. According to Sim et al. (1990), it is not suitable to take the difference form of variables to the VAR model because the tendency in variables will be lost. In this study, the variables, reer, $h p$ and $s p$, fail to pass unit root test. However the primary purpose of this paper is to estimate the SVAR model using variables in their levels to analyze the dynamic relationship among these variables rather than parameter estimation. Specifically, the paper intends to investigate how the current account responds to shocks to real exchange rate, real housing prices and real stock prices.

The second step is to impose restrictions on the short-run behavior of the VAR system in equation (2). The random stochastic residual $A^{-1} B u_{t}$ can be estimated from the residual $e_{t}$ of the estimated unrestricted VAR model by the following expression:

$$
A^{-1} B u_{t}=e_{t}
$$

By reformulating equation (3), $A^{-1} B u_{t} u_{t}^{\prime} B^{\prime} A^{\prime-1}=e_{t} e_{t}^{\prime}$ can be obtained. Since $u_{t} u_{t}^{\prime}=I$, thus

$$
A^{-1} B B^{\prime} A^{-1}=e_{t} e_{t}^{\prime}
$$

Let $k$ be the number of variables in the system. The symmetry property of equation (4) requires imposing $k(k+1) / 2$ restrictions on the $2 k^{2}$ unknown elements in matrices $\mathrm{A}$ and $\mathrm{B}$. Therefore, additional $\mathrm{k}(3 \mathrm{k}-1) / 2$ restrictions must be imposed. The restriction scheme is in the form:

$$
A e_{t}=B u_{t}
$$




\section{Macrothink}

Business and Economic Research

ISSN 2162-4860

2017, Vol. 7, No. 2

The short-run restrictions can be imposed in terms of the vector of residuals, et, which is obtained from the estimate of an unrestricted VAR model. The vector of the fundamental random errors, ut, is obtained from the structural system. Equation (5) can be expressed as:

$$
\left[\begin{array}{ccc}
1 & 0 & 0 \\
a 21 & 1 & 0 \\
a 31 & a 32 & 1
\end{array}\right]\left[\begin{array}{l}
e 1 \\
e 2 \\
e 3
\end{array}\right]=\left[\begin{array}{ccc}
b 11 & 0 & 0 \\
0 & b 22 & 0 \\
0 & 0 & b 33
\end{array}\right]\left[\begin{array}{l}
u 1 \\
u 2 \\
u 3
\end{array}\right]
$$

With 3 variables in the system, the number of restrictions is $9 .^{2}$ Imposing restrictions will make the system just-identified.

The results from the estimated SVAR models can be used to obtain the impulse response functions and structural variance decompositions.

\section{Empirical Results}

In this section, impulse responses and variance decompositions are analyzed. The SVAR model of equation (6) is estimated. As mentioned in Sub-Section 3.2, there are two VAR models to be estimated. The first model comprises the current account ( $c a$ ), real effective exchange rate (reer) and real housing prices $(h p)$. The second model comprises the current account $(c a)$, real effective exchange rate (reer) and real stock prices $(s p)$.

Since the SVAR methodology assumes that the structural innovations or the underlying shocks are orthogonal, the coefficients of Matrix B should be statistically significant. The estimated coefficients of the first model are presented in Table 3.

Table 3. Estimated Coefficients for the Structural Model (ca, reer, $h p)$

\begin{tabular}{|c|c|c|}
\hline \multicolumn{3}{|c|}{ Matrix A: } \\
\hline & Coefficient & $\mathrm{p}$-Value \\
\hline$a_{21}$ & -0.108 & 0.315 \\
\hline$a_{31}$ & -0.182 & 0.067 \\
\hline$a_{32}$ & -0.249 & 0.116 \\
\hline \multicolumn{3}{|c|}{ Matrix B: } \\
\hline & Coefficient & $\mathrm{p}$-Value \\
\hline$b_{11}$ & 4.066 & 0.000 \\
\hline$b_{22}$ & 2.513 & 0.000 \\
\hline$b_{33}$ & 2.285 & 0.000 \\
\hline
\end{tabular}

Note: Convergence is achieved after 4 iterations.

The results in Table 3 show that the estimated coefficients of the orthogonal matrix are significant at the 1 percent level. The estimated coefficients of the second model are presented in Table 4.

\footnotetext{
${ }^{2}$ Blanchard and Quah (1989) impose long-run restrictions on the system such that some variables have no long-run effects while the restrictions mentioned in this paper are short-run restrictions, which determine which variables are allowed to have non-zero response to a given shock in the identified system.
} 
Table 4. Estimated Coefficients for the Structural Model (ca, reer, sp)

\begin{tabular}{|c|c|c|}
\hline \multicolumn{3}{|c|}{ Matrix A: } \\
\hline & Coefficient & p-Value \\
\hline$a_{21}$ & -0.012 & 0.894 \\
\hline$a_{31}$ & 1.353 & 0.702 \\
\hline$a_{32}$ & 15.615 & 0.022 \\
\hline \multicolumn{3}{|c|}{ Matrix B: } \\
\hline & Coefficient & p-Value \\
\hline$b_{11}$ & 4.568 & 0.000 \\
\hline$b_{22}$ & 2.375 & 0.000 \\
\hline$b_{33}$ & 92.875 & 0.000 \\
\hline
\end{tabular}

Note: Convergence is achieved after 4 iterations.

The results in Table 4 also show that the estimated coefficients of orthogonal matrix are significant at the 1 percent level. Therefore, it can be concluded that two estimated SVAR models are just-identified. Therefore, impulse response functions and variance decompositions can be analyzed from the estimated SVAR models.

\subsection{Impulse Response Functions}

The estimated impulse responses of the current account due to a one-standard deviation shocks in real effective exchange rate and real housing prices are displayed in Figure 4. Impulse response functions are obtained from the estimate of SVAR model comprising current account, real exchange rate and real housing prices. The left figure shows how the current account ( $c a$ ) responds to shocks to real exchange rate (reer) while the right figure shows how the current account $(c a)$ responds to shocks to real housing prices $(h p)$. The response horizon measured in quarters is given on the horizontal axis. It is apparent that real exchange rate shocks start to cause the current account to decrease in the second quarter. The negative impact gradually decreases and dissipates in the seventh quarter. This result is in line with Blanchard and Giavazzi (2002), but the current account effect of exchange rate shift is temporary. The housing price shocks cause the current account to increase in the second quarter. This positive impact decrease thereafter, but never dissipate. The positive impact of housing price shock on the current account seems to be consistent with the finding by Fratzscher et al. (2010). It should be noted that there is an assertion that a rising trend of asset prices causes expected income and thus consumption of households to increase. This phenomenon in turn causes imports to increase and leads to a deterioration of an economy's trade balance. However, this negative relationship between housing prices and current accounts is not supported by empirical evidence. 
Response to Structural One S.D. Innovations

Response of ca to reer shock

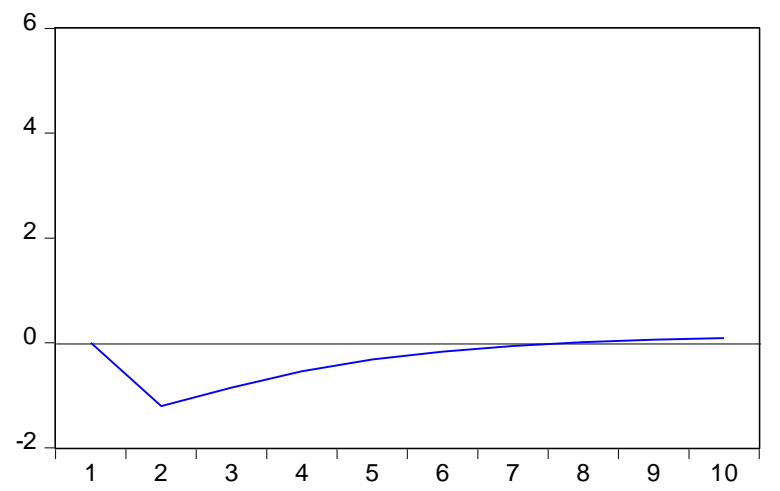

Response of ca to hp shock

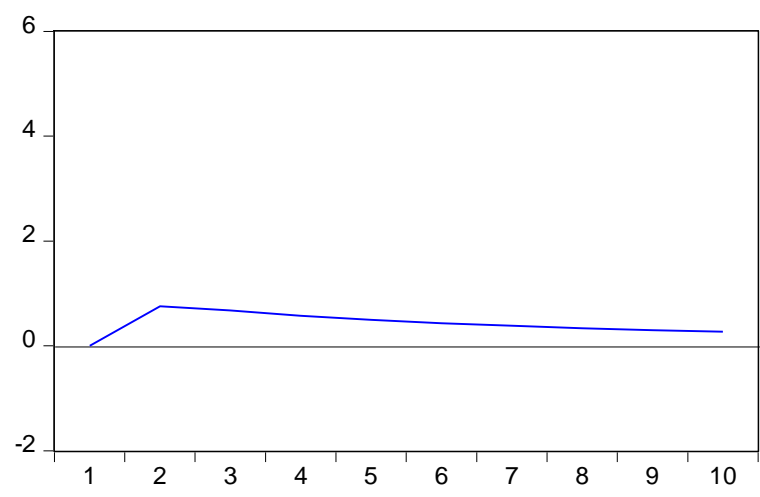

Figure 4. Impulse Responses of the Current Account to Shocks to Real Effective Exchange Rate and Real Housing Prices

The estimated impulse responses of the current account due to a one-standard deviation shocks in real effective exchange rate and real stock prices are displayed in Figure 5.

Response to Structural One S.D. Innovations

Response of ca to reer shock

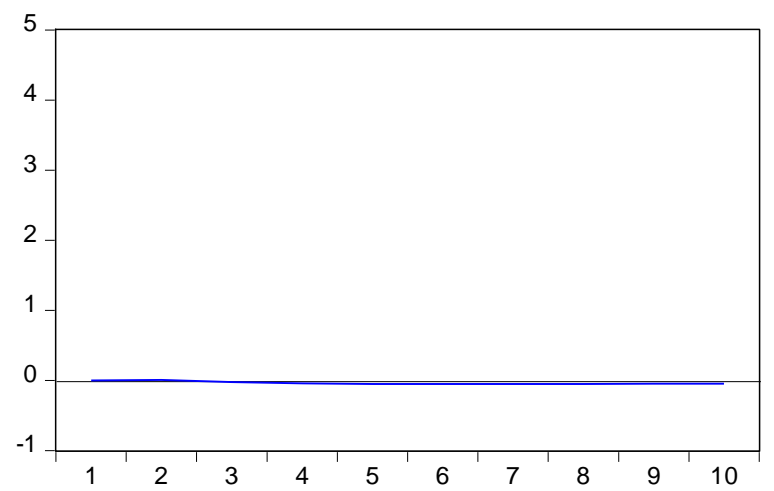

Response of ca to sp shock

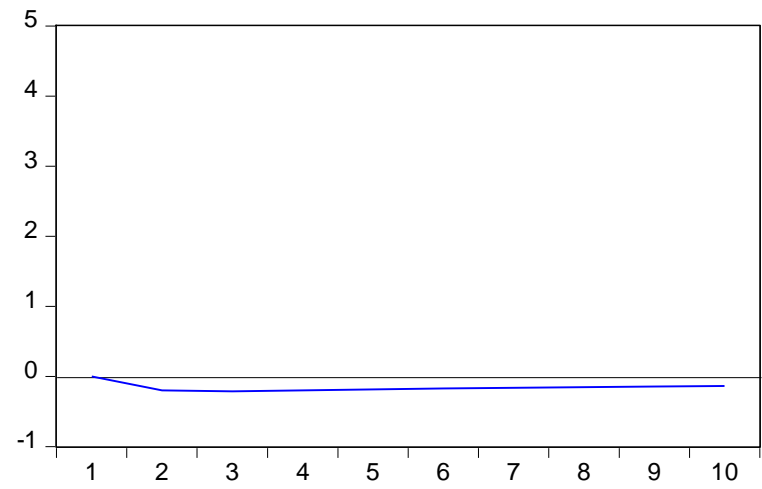

Figure 5. Impulse Responses of the Current Account to Shocks to Real Effective Exchange Rate and Real Stock Prices

Impulse response functions in Figure 5 are obtained from the estimate of SVAR model comprising current account, real exchange rate and real stock prices. The left figure shows how the current account ( $\mathrm{ca}$ ) responds to shocks to real exchange rate (reer) while the right figure shows how the current account $(c a)$ responds to shocks to real stock prices $(s p)$. It can be observed from the figure that the negative impact of shocks to real exchange rate on the current account is almost negligible even though this impact lasts until the ninth quarter. The impact of shocks to stock prices on the current account starts with a lag of one quarter. The current account starts to fall slightly after the first quarter and remains significant thereafter. This result is contradictory to some previous findings in advanced countries, for examples, the findings by Blanchard et al. (2005), Fratzscher and Straub (2009) and Berg (2013). 


\subsection{Variance Decompositions}

Table 5 reports the variance decompositions of the current account, which allow for calculation of the proportion of the fluctuations in a series due to its own shocks versus shocks to the other variables.

Table 5. Forecast Error Variance Decomposition of Current Account Explained by Shocks to Real Effective Exchange Rate and Real Housing Prices

\begin{tabular}{|l|l|l|}
\hline Forecast Horizon & Real Exchange Rate & Real Housing prices \\
\hline 1 & 0.00 & 0.00 \\
\hline 2 & 7.82 & 3.05 \\
\hline 5 & 12.39 & 7.67 \\
\hline 10 & 12.13 & 10.20 \\
\hline
\end{tabular}

Note: The number in each row shows the percentage of current account fluctuations explained by shocks.

The results are in accordance with the impulse response analysis in Figure 4. The results show that two quarters after the impact, the shocks to real effective exchange rate explain 7.82 percent of fluctuations in the current and 3.05 percent explained by the shocks to housing prices.

Table 6. Reports the variance decompositions of current account due to shocks to real effective exchange rate and shocks to real stock prices

\begin{tabular}{|l|l|l|}
\hline Forecast Horizon & Real Exchange Rate & Real Stock prices \\
\hline 1 & 0.00 & 0.00 \\
\hline 2 & 0.00 & 0.19 \\
\hline 5 & 0.02 & 0.74 \\
\hline 10 & 0.08 & 1.29 \\
\hline
\end{tabular}

Note: The number in each row shows the percentage of current account fluctuations explained by shocks.

The results are in accordance with the impulse response analysis in Figure 5. The results indicate that both shocks to real exchange rate and real stock prices are not primary sources of the fluctuations in current account compared to the role of shocks to real exchange rate and real housing prices on trade balance. However, real stock price shocks seem to be slightly more important than real exchange rate shocks. More precisely, two quarters after the impact, the shocks to real effective exchange rate do not explain fluctuations in the current account and only 0.19 percent is explained by the shock to real stock prices.

It can be concluded that the structural model that comprises housing prices, real effective exchange rate, and the current account is more applicable in the case of Thailand because the Thai stock market is not well-developed. For policy implications, the measures that prevent domestic currency depreciation and stimulate the housing market can improve the current account at least in the short run. However, there are other important shocks that can exert more substantial impacts on the current account that policy makers should take into account, such as supply shocks and output shocks (see Karadimitropoulos and Leon-Ledesma, 2009, among others). 


\section{Conclusion}

This paper examines the impacts of shocks to asset prices and real effective exchange rate on the current account in Thailand during 2008Q1 and 2016Q2. Two structural VAR models with short-run restrictions are used to obtain the just-identified systems. It is found that the response of the current account to the shocks to real effective exchange rate and real housing prices is more apparent than the response of the current account to the shocks to real effective exchange rate along with real stock prices. In other word, the model that allows for interactions among housing prices, real effective exchange rate and the current account seems to be suitable in explaining the current account fluctuations. Based upon the results from this study, policymakers should take into account the importance of foreign exchange market and the housing market boom that can affect the current account.

This paper has some limitations due to the availability of housing price data. Therefore, relatively small sample size is left for the analysis. With relatively small size of observations, there should not be structural shifts and thus a robustness test is not necessary. Furthermore, other factors that can have substantial impacts on the current account are excluded to preserve the degree of freedom. Thus, the analysis of the more complete structural model is left for future research when a larger number of observations of housing price index are available.

\section{References}

Ahmed, S., \& Park, J. H. (1994). Sources of Macroeconomic Fluctuations in Small Open Economies. Journal of Macroeconomics, 16, 1-36.

https://doi.org/10.1016/0164-0704(94)90042-6

Antonakakis, N., Gupta, R., \& Tiwari, A. K.,(2015). Time-varying Correlations between Trade Balance and Stock Prices in The United States over the Period 1792 to 2013. Working Paper, Department of Economics, University of Pretoria.

Arestis, P., \& Gonzale-Martinez, A. R. (2016). House Prices and Current Account Imbalances in OECD countries. International Journal of Finance and Economics, 21, 58-74.

https://doi.org/10.1002/ijfe.1523

Ballano, J., \& Ibrahimaj, D. (2015). Current Account Determinants in Central Eastern European Countries. HEID Working Paper No. 22-2015, Economics Sections, The Graduate Institute of International Studies.

Beckmann, J., \& Czudcy, R. (2016). Effective Exchange Rates, Current Account and Global Imbalances. Ruhr Economic Paper No. 610, Ruhr University Bochum, TU Dortmund University, University of Duishurg-Essen. https://doi.org/10.2139/ssrn.2759200

Berg, T. O. (2013). Cross-Country Evidence on the Relation between Stock Prices and Current Account. Applied Economics, 45, 2267-2277.

https://doi.org/10.1080/00036846.2012.659349

Blanchard, O. J., \& Giavazzi, F. (2002). Current Account Deficits in the Euro-area: The End of the Feldstien-Harioka Puzzle? Brooking Papers on Economic Activity, 33, 147-210. 
https://doi.org/10.1353/eca.2003.0001

Blanchard, O. J., Giavazzi, F., \& Sa, F. (2005). International Investors, the Current Account, and the Dollar. Brooking Papers on Economic Activity, 36, 1-66.

https://doi.org/10.1353/eca.2005.0010

Blanchard, O. J., \& Quah, D. T. (1989). The Dynamic Effects of Aggregate Demand and Supply Disturbances. American Economic Review, 79, 655-673.

Chinn, M. D., \& Lee, J. (2009). Three Current Account Imbalances: A 'Semi-Structuralist' interpretation. Japan and the World Economy, 21, 202-212.

https://doi.org/10.1016/j.japwor.2008.05.001

Fratzscher, M., Luciana, J., \& Sarno, L. (2010). Asset Prices, Exchange Rate and Current Account. European Economic Review, 54, 643-658.

https://doi.org/10.1016/j.euroecorev.2009.12.005

Fratzscher, M., \& Straub, R. (2009). Asset Prices and Current Account Fluctuations in G-7 Economies. IMF Staff Papers, 56, 633-654. https://doi.org/10.1057/imfsp.2009.8

Fratzscher, M., \& Straub, R. (2013). Asset Prices, News Shocks and Trade Balance. Journal of Money, Credit and Banking, 45, 1211-1251. https://doi.org/10.1111/jmcb.12050

Holinski, N., \& Vermeulen, R. (2012). The International Wealth Channel: A Global Error-Correcting Analysis. Empirical Economics, 43, 985-1010.

https://doi.org/10.1007/s00181-011-0514-8

Karadimitropoulos, A., \& Leon-Ledesma, M. A. (2009). Sources of Current Account Fluctuations in Industrialized Countries. Working Paper, Department of Economics, University of Kent.

Krugman, P. (2007). Will There be a Dollar Crisis? Economic Policy, 22, 435-407. https://doi.org/10.1111/j.1468-0327.2007.00183.x

Lee, J., \& Chinn, M. D. (2006). Current Account and Real Exchange Rate Dynamics in the G-7 Countries. Journal of International Money and Finance, 25, 257-274. https://doi.org/10.1016/j.jimonfin.2005.11.002

Mercereau, B. (2003). The Role of Stock Markets in Current Account Dynamics: A Time Series Approach. B. E. Journal of Macroeconomics, 3, 1-30.

https://doi.org/10.2202/1534-5998.1063

Mirdala, R. (2013). Current Account Adjustment and Real Exchange Rates in European Transition Economies. Journal of Applied Economic Sciences, 8, 210-227.

Obstfeld, M., \& Rogolf, K. (1995). Exchange Rate Dynamic Redux. Journal of Political Economy, 103, 624-660. https://doi.org/10.1086/261997

Sek, S. K., \& Chuah, C. (2011). The Dynamic of Current Account in Emerging East-Asian: Does Exchange Rate Matter? International Journal of Trade, Economics and Finance, 2, 
293-299.

Sim, C. A., Stock, J. H., \& Watson, M. W., (1990). Inference in Linear Time Series Models with Some Unit Roots. Econometrica, 58(1), 113-144. https://doi.org/10.2307/2938337

Simo-Kengne, B. D., Gupta, R., \& Aye, G. C. (2015). House Prices and Balance of Trade Dynamics in South Africa: Evidence from an Agnostic Identification Procedure. Journal of Housing Research, 24, 107-126.

\section{Copyright Disclaimer}

Copyright for this article is retained by the author, with first publication rights granted to the journal.

This is an open-access article distributed under the terms and conditions of the Creative Commons Attribution license (http://creativecommons.org/licenses/by/3.0/). 